\title{
Disclosure of Communication in the Facebook and Impact Social Media on Worship Activities in Dakwah Faculty Students and Science of Communication Media of North Sumatera State University (UINSU)
}

\author{
Marlina $^{1 \text { ab }}$, Moh. Hatta ${ }^{2}$, Suwardi Lubis ${ }^{3}$ \\ la PhD Student in Universitas Islam Negeri Sumatera Utara, Indonesia \\ ${ }^{1 b}$ Lecturer in Sekolah Tinggi Agama Islam Negeri Mandailing Natal, Indonesia \\ ${ }^{2}$ Universitas Islam Negeri Sumatera Utara, Indonesia \\ ${ }^{3}$ Universitas Sumatera Utara, Indonesia \\ marenzhy@yahoo.co.id
}

\begin{abstract}
This study aims to reveal the extent of openness of communication carried out among students of the Da'wah Faculty and UINSU communication and its impact on worship activities carried out by these students. Observations and interviews are techniques used to collect data in this study. Triangulation analysis method is also used to analyze the data obtained from respondents, descriptive analysis research method applied in this study. From 30 respondents taken with a percentage of 20 female respondents and 10 male respondents it was found that social media activities through Facebook had a special attraction and increased their confidence in communication. The impact felt by the respondents was more to the shift in the discipline of worship that they did when cool communicating with their virtual friends, recitations of the Koran that are usually done before prayer time arrives multiplied by the fun they are chatting, status updates or just looking at their Facebook wall.
\end{abstract}

Keywords

openness to communicate; social media; impact; alternative communication media

\section{Introduction}

Communication is the process of delivering messages by someone to other people to tell, change attitudes, opinions or behavior either directly orally or indirectly through the media. In this communication requires a reciprocal relationship between the delivery of messages and recipients namely communicators and communicants. (Hasbullah, 2018)

Communication activities today are experiencing a very significant shift, everyone, face-to-face communication has been replaced by media communication, the words "bring the far and move close" is the right sentence to describe the phenomenon of communication that exists at this time, the use of smartphones not for the function as it should be, but the use of smartphones tends to be a place to determine the social status that is carried by someone, this is a very worrying campsite, not only is the use side that makes distance for someone but the nature of communication has been replaced.

Communication through social media promises a comfortable state of communication, where someone who cannot compose words can be someone who is very poetic, with a very relaxed appearance and state, someone can carry out communication activities with others, lecturers, or someone when we communicate with it must take care of all things, appearance and style of language, but communicating through social media do not have to pay attention to it, sit back with a cup of coffee and use casual clothes a person can carry out communication activities. 
Communication carried out by a person also takes place in a variety of contexts, ranging from interperseonal communication, intrapersonal communication, group communication, organizational communication to mass communication, each of which has unique characteristics or characteristics and is a differentiator between the communication context all of which require effectiveness in the process of communication interaction. There are eight characteristics of interperseonal communication put forward by Richard L. Weaver, namely: involving at least two people, feedback occurs, it can happen even though not face to face, does not have to have the same goal, there will be some effect or influence later, does not have to using verbal communication, Influenced by context and Influenced by noise or problems.

In interperseonal communication the context that covers it is the physical, social, cultural, cultural and psychological aspects of a person who communicates. If a communication that is carried out in an atmosphere that is not conducive, which is motivated by a noisy atmosphere and many distractions, will produce a different perspective or meaning if the communication is carried out in a more conducive and conducive atmosphere, this is a description of a physical context.

North Sumater UIN students, especially the Faculty of Da'wah and Communication Science are students who before the widespread use of samartphone, had good worship activities, besides that the communication activities carried out by fellow students were very friendly and relaxed, but the phenomenon had been replaced as the usage increased. smartphone that has advanced features and the use of other applications, especially social media. Tilawah, muraja'ah and ta'lim or just the activity of doing tasks in groups, now is a slightly rare sight, before the rise of the use of smartphones, especially Facebook, the scenery as described above is very much found in the form of groups.

This research is very important to do, considering that communication activities through Facebook are very widespread, especially students of the Faculty of Da'wah and Communication Science of North Sumatra UIN. The use of social media and its impact on the openness of a communication activity and its impact on worship activities, must be a particular concern, why such communication activities are extremely attention grabbing and can shift openness of communication and the severity of which can turn worship activities into communication activities in cyberspace which have their own allure, what causes this to happen, besides that the importance of this research is to anticipate "social media opium" among students, which students should learn to create a healthy network for their future, not to build networks in cyberspace, let alone just be follower or talkative communication activities.

\section{Review of Literatures}

The theory that researchers consider relevant to the title of this study, namely the theory of social action from Max Weber is actually based on Weber's interest in the subjective meaning given by individuals to their actions. Weber focused on the intersubjective and intrasubjective of human thought that marks social action. For him the main issue of sociology is the process of defining social and the consequences of an action and social interaction. Therefore, in his research, to study such phenomena about intersubjectives and intrasubjectives, Weber suggests using interpretative-understanding methods or better known as methods verstehen. The more important issue according to Weber is sociology engaged in an effort to understand at the level of meaning, and try to find an explanation on the internal factors that exist in society itself. 
Heider balance theory This theory deals with how a person arranges attitudes towards people or objects in doing relationships with one another that is contained in his own cognitive structure, Heider is very concerned with the way a person arranges attitudes towards others and objects where they relate to one another the other, Heider argues, if the relationship is established with an unbalanced state, we can be sure that the relationship will recover and as if through stresses and tensions, the concept of a balanced state shows a situation in which existing units and sentiments exist. experienced "living" side by side without pressure. In addition to the above theories, there are several theories that are also used later in this study, namely; Relationship Rules Approach, Social Exchange Theory, Equity Theory, Symbolic interaction theory.

\section{Research Methods}

This research is a qualitative study, which is often equated with naturalistic research that seeks to understand how people perceive the world by examining how they communicate. According to Bogdan and Taylor qualitative research is a research procedure that produces descriptive data in the form of written or oral words from people and observable behavior. The qualitative approach is characterized by research objectives that seek to understand symptoms in such a way that do not require quantification, because symptoms do not allow it to be measured precisely. Furthermore, this qualitative method has several ways that are tailored to the needs of the required data. Mulyana mentioned that, the qualitative research method was carried out in a descriptive manner (unstructured interviews / in-depth interviews, participatory observation), document analysis, case studies, critical historical studies; interpretation is emphasized rather than objective observation.

This study wants to see UIN students who communicate through social media naturally as humans who construct social reality. students are seen as a community that has its own reality and is different from the others. Through interviews that will be conducted on North Sumatra UIN students with a list of questions that lead to how they do communication, what is discussed and so forth that are considered to be able to collect data and information that leads to openness and ethics conducted by North Sumatra UIN students in conducting communication on social media, as well as matters relating to what will be studied later. Interview is a special form of interpersonal communication where two or more people conduct question and answer activities aimed at achieving certain goals, interviews are also carried out face to face and some are through the media by telephone, email and so forth

\subsection{Research subject}

The subjects of this study were North Sumatra UIN students who were students and were in the early semester, and were conducted by interview method. So, not all students are made as research informants. Informants in this study consisted of basic informants and key informants (key informants). The base informant is a person who is considered capable of providing information in general and is able to appoint others as the main informants who can provide more in-depth information. Meanwhile, the object of this research relates to the openness of communication made by North Sumatra UIN students through social media, in the form of relationships they make with anyone, as well as the use of words they post through social media and how they respond or respond to a status, and which has become a habit of sharing their status with cyberspace audiences. 


\subsection{Data Source}

The entire data required consists of two parts, namely primary and secondary data. Primary data were obtained from in-depth interviews and observations about communication activities carried out on social media by North Sumatra UIN students, while secondary data were obtained from various references, research results or documentation in the form of written sources, such as books, scientific journals, and also other sources.

\subsection{Technique Collection of Data}

Data collection techniques in a qualitative approach are done through observations and interviews conducted openly and in depth, observation and interviews are to observe and record systematically and planned about social phenomena that occur in the community, in the techniques and stages of data conclusions researchers consider at least four measures that is; where the research takes place, the actors or people involved in the research to be interviewed or observed, the event is what will be observed and observed and finally the process is the nature carried out in the setting of the event.

The steps in data collection involve, among others: 1) establishing research boundaries; 2) gathering information through observation, interviews, documents and materials; and 3) establish rules for recording information. The idea of qualitative research is to deliberately choose informants (or documents or materials) that can provide the best answers to research questions. Researchers must consider the four measures suggested by Miles \& Huberman; setting (where the research will take place), actors (people to be observed or interviewed), events (what will be observed or observed), and processes (the nature of events carried out in the setting).

Observations in this study were conducted to obtain data relating to communication made through social media, both with the use of words (verbal), posting pictures and signs used, interviews in this study will be carried out in depth by trying to put yourself researchers parallel to research informant. So the data needed can really be revealed through this technique. Meanwhile, documentation is the matters related to the activities carried out when they carry out communication with social media, when what and with what circumstances. Likewise, other data that support the improvement of data in this study.

\subsection{Validity and Data Analysis}

To measure and show that the data in this study are valid, a test of the truth and honesty of the subject in revealing reality according to what is experienced, felt or imagined, is known as trustworthines. This method includes triangulation analysis that is analyzing the subject's answer by examining its truth with empirical data (other available data sources). In this method the subject's answers are cross-checked with existing documents. The method of triangulation analysis is very varied, but in this study the method of triangulation is used; an attempt to check the validity of the data or research findings. Method triangulation can be done by using more than one data collection technique to get the same.

\section{Result and Discussion}

\subsection{Openness to Communicate on Social Media}

Communicating using social media like Facebook has a different pattern when we communicate directly. The character that is shown by communication actors when conducting communication activities through social media often we find very different things. When communication activities are carried out directly we often find communication rigidity because it is direct without intermediaries. As revealed by Masitah Student 
Communication and Broadcasting Islam 5th semester "I usually like being shocked when talking to someone directly, because I'm a shy person, different from when I chat on Facebook, I can still think about what words I would say first"

The same thing was also expressed by Andika, one of Semeter 5 Students "I like to be confused and think hard when asked directly, I am not a quiet person, but like to be reluctant when talking directly, afraid that there will be hurt because I often speak spontaneously."

Words that are often expressed when interacting with others on social media often show things that are pleasing to the other person, when making comments on the status posted by someone a lot of considerations that must be taken into consideration. The language expressed often shows conditions that are far different from what we really want to express. Ethically, when we interact on someone's Facebook Wall, it means that we are entering someone's house, then ethically we will interact using polite language, without hurting, it also makes the facebook account owner offended by the words we convey.

In line with Heider's theory, it discusses how a person arranges attitudes towards people or objects in doing relationships with one another that is contained in their own cognitive structure. By the way someone arranges attitudes towards other people and objects where they are related to one another.

Very often comments that are only lip service to make the account owner happy to be delivered, there are also many comments that are agreeable to the statement posted by the owner of the Facebok account, although it is often found that the status displayed by the account holder is not good, or is a hoax. This is the same as expressed by Maya, a third semester student majoring in Communication and Broadcasting Islam "I actually want to say, the style of photos and language is improved if you want to be displayed on social media. If you want to give input, then I am jealous of him, so let's say ... "

"It's rarely honest to comment, unless I've felt uncomfortable about someone's status. In addition, I also often make a status that insinuates not having that address, If I immediately tag the person later offended "hasyim", a student of Islamic Broadcasting Communication semeter 3.

Openness when communicating on Facebook social media is mostly just lip service, because the language and comments that are often spoken only indicate a desire to just participate, openness like wanting to say the truth when there are friends posts that are wrong or incorrect and should not be, often the number two. They more often make small talk and give a comet that is pseudo, without wanting to give input in the form of criticism even though it is painful. Openness is only valued as a sweetener.

In line with the above interview expression with Heider's theory states, if the relationship is established with an unbalanced state, it is certain that the relationship will recover and as if through stresses and tensions, the concept of a balanced state shows a situation in which the units are there are sentiments experienced by "living" side by side without pressure.

\subsection{The Impact of Social Media on Student Worship Activities in the Da'wah Faculty of UIN SU}

The worship activities referred to in this study are sunnah worship after or before the fard prayer, such as recitations and muraja'ah together, the place of implementation of the worship activities referred to in this study are worship activities at the Al-izzah mosque in North Sumatra UIN. Before the rise of smartphone usage and facebok social media usage style among UIN North Sumatra students Especially the Da'wah Faculty and communication students, in general students often do religious activities around the Al-izzah Mosque of UINSU. While waiting for the lecturer to enter or waiting for the change of course or even 
just to let go of fatigue, many students attended the mosque to carry out religious activities as explained earlier.

Students will carry out these ibdah activities in groups, to be done individually or individually. The worship in question is like reciting the tilawah and muarajaa together. The activity was marked by the number of groups scattered around the Alizzah Mosque. The group is made up of at least 6 to 8 people and is guided by one brother mentor. Their gathering to recite and carry out activities is a scene that is commonly found around the Alizzah UINSU mosque. Siantia of the 3rd semester students confirmed the above "We would feel reluctant if sitting not participating in the study, it seems all eyes will be directed at me. Feeling and embarrassed. " This habit gradually changed, Alizzah mosque was filled with many students who gathered just to rest without doing religious activities. Not infrequently many students who do not pray also come to.

This habit is also formed by itself when smartphone users and the more widespread students have a Facebook account. The use of Facebook among students in the Faculty of da'wah and communication makes worship activities increasingly fade, they will perform compulsory worship directly, without carrying out other religious and religious activities. This phenomenon is based on the intensity of students communicating using Facebook.

In line with Max Weber's theory of social action, the main problem of sociology is the process of defining social and the consequences of an action and social interaction. sociology is engaged in trying to understand at the level of meaning, and trying to find an explanation on the internal factors that exist in society itself.

Facebook is a social media account that is very easy to use, in addition to easy development Facebook is also increasingly experiencing rapid progress, users and Facebook account owners are increasingly spoiled with facilities that continue to be improved. Murdanil, a final semester student, said that "many things have changed, usually in the mosque liqo is done" in every corner of the mosque, now there is an increase in mosque visitors, especially women, but not infrequently the students who attend are just looking for cool seats, to open their Facebook accounts "

"A few years ago everyone who sat around and made a circle was definitely an LDK child who was mentoring. But now I get confused a lot of times that come but no one mentoring. They just sit and hold their cellphones and status updates or even comment on the left and right on Facebook, "said a statement from widiya, a third semester student majoring in Islamic Communication and Broadcasting.

The use of Facebook has a significant influence in worship activities among students of the Da'wah Faculty and UIN North Sumatra communication, so that communication in cyberspace has its own appeal for students. This can be seen from the changing pattern of activities of students communicating directly to student worship activities also began to experience a shift.

Students will feel comfortable and free expression when they do the activity of communication on Facebook social media, "can meet old friends who are now far away, get new acquaintances, can watch movies and play together directly, there are still lots of fun playing facebook," has the world itself, as well as recognition from people who have not met for a long time also from new acquaintances, one of the factors of attraction for Facebook use.

\section{Conclusion}

Communicating through social media, especially Facebook is both personal through massenger or through comments on the status of one's homepage has a special attraction. Can communicate with distant friends who have not met for a long time. Play a role and 
remember the past. Sharing moments in the form of photo documents, videos can even be broadcast live and directly commented by friends or new acquaintances are new and interesting communication styles.

There will still not be many media-mediated communication activities especially on social media. Giving praise and comments that only make the reader or owner happy status without wanting to give something honest to them, is one of the characteristics of communication activities carried out through Facebook. In line with Heider's theory which states, if the relationship is established with an unbalanced state, it is certain that the relationship will recover and as it did through stresses and tensions. The concept of a balanced state shows a situation in which existing units and sentiments experienced "live" side by side without pressure.

Although communication is lip service, many people feel comfortable doing media communication. Starting from wanting to be praised, referred to as someone who exists and likes adventure is something that wants to be shown when someone displays their daily activities on social media. In line with Max Weber's theory of social action, the main problem of sociology is the process of defining social and the consequences of an action and social interaction. sociology is engaged in trying to understand at the level of meaning, and trying to find an explanation on the internal factors that exist in society itself.

\section{References}

A. Michael Huberman \& Matthew B. Milles. (1992). Analisis Data Kualitatif. Terjemahan Tjetjep Rohendi, UI-Press, Jakarta.

Burhan Bungin. (2004). Metodologi Penelitian Kualitatif , Kencana,Jakarta.

Dian wisnu Wardhani, sri fatmawati mashoedi. (2012). Hubungan Interpersonal, salemba Humanika, Jakarta.

Deddy Mulyana. (2003). Metodologi Penelitian Kualitatif: Paradigma Baru Ilmu Komunikasi dan Ilmu Sosial Lainnya, PT. Remaja Rosdakarya,Bandung.

James P Pratley. (1997). metode Etnografi, Tiara Wacana,Yogyakarta.

Hasnullah, et al . (2018). Communication Pattern of Wilayatul Hisbah, Lhokseumawe City in Implementing Amar Makruf Nahi Mungkar. Budapest International Research and Critics Institute-Journal (BIRCI-Journal). P. 194-205

Judistira K. Garna. (1991) Teori-Teori Perubahan Sosial , Program Pascasarjana Universitas Padjadjaran, Bandung.

John W. Cresswell. (1994) Qualitative Inquiry and Research Design Choosing Among Five Traditions, Sage Publication,London.

Koentjaraningrat. (1991). Metode-Metode Penelitian Masyarakat, PT. Gramedia, Jakarta.

Kriyantono. (2012).Teknik Praktis Riset Komunikasi, Kencana Prenada Media Grup, Jakarta.

Lexy J. Moleong, 2000, Metodologi Penelitian Kualitatif , PT. Remaja Rosdakarya,Bandung.

Suciati. (2015). komunikasi interpersonal sebuah tijauan psikologis dan persfektif Islam. Litera. Yogyakarta

Suwardi Endraswara. (2006).Metode, Teori, Teknik Penelitian Kebudayaan: Ideologi, Epistemologi, dan Aplikasi, Pustaka Widyatama, Yogyakarta

Winarno surakhmad. (1990). pengantar penelitian ilmiah; dasar dan tekhnik metode, Tarsito,Bandung.

Zamroni. (1992). Pengantar Pengembangan Teori Sosial, PT. Tiara Wacana, Yogyakarta. 